\title{
Productivity Potential of Wheat under Certified Organic Production System
}

\author{
Sandeep Kumar* and Thomas Abraham \\ Department of Agronomy, Naini Agricultural Institute, Sam Higginbottom University of \\ Agricultural, Technology \& Sciences (Formerly Allahabad Agricultural Institute) \\ Allahabad - 211007 Uttar Pradesh, India \\ *Corresponding author
}

\section{A B S T R A C T}

\section{Keywords}

FYM, Poultry manure, Vermicompost, Goat manure, Grain yield, wheat

Article Info

Accepted:

04 September 2018

Available Online:

10 October 2018
A field experiment was conducted during winter ( $r a b i)$ season of last week of December 2015 at the certified organic experiment farm of the SHIATS Model of Organic Farm (SMOF) in NAI, Allahabad to study the response of wheat cultivars to different sources of organic nitrogen nutrient on growth and yield of wheat. The experiment consist fifteen treatments with four replication laid out split plot design. Three cultivars and Five organic sources i.e., control (kharif green manure), FYM $\left(15 \mathrm{t} \mathrm{ha}^{-1}\right)$, Poultry manure $\left(4 \mathrm{t} \mathrm{ha}^{-1}\right)$, vermicompost $\left(6 \mathrm{tha}^{-1}\right)$, and goat manure $\left(5 \mathrm{t} \mathrm{ha}^{-1}\right)$. The result revealed that the treatment $\mathrm{T}_{12}$ [PBW $502+$ Poultry manure $\left(4 \mathrm{t} \mathrm{ha}^{-1}\right)$ ] recorded significant and highest number of effective tillers (7.23) and grain yield (3.95 $\mathrm{ha}^{-1}$ ) which was $107.77 \%$ higher than the lowest grain yield $\left(1.93 \mathrm{t} \mathrm{ha}^{-1}\right)$ observed in treatment $\mathrm{T}_{0}$ [ PBW $373+$ control]. However, the highest straw yield $\left(5.78 \mathrm{t} \mathrm{ha}^{-1}\right)$ recorded was treatment $\mathrm{T}_{11}$ [PBW $502+\mathrm{FYM}(15 \mathrm{t}$ $\left.\mathrm{ha}^{-1}\right)$ ]. On the basic of result it is conclude that the treatment combination $\mathrm{T}_{12}$ [PBW $502+$ Poultry manure $\left(4 \mathrm{tha}^{-1}\right)$ ] found to be highest number of effective tillers, test weight, grain yield and straw yield.

\section{Introduction}

Wheat (Triticum aestivum L.) is the world's most outstanding crop that excels all other cereals both in area and production, known as king of cereals. It has grown throughout the temperate, tropical and sub-tropical region in the world. It constitutes the staple food in at least 43 countries.

In India wheat is the second most important cereal crop and plays a key role in food and nutritional security (IIWBR, 2015), India has cultivated wheat in an area of 30.47 and 30.9 million hectares with total production of 95.85 and 88.95 million tonnes and productivity of 3177 and $3117 \mathrm{~kg} \mathrm{ha}^{-1}$ during 2014 and 2015 respectively (GOI, 2015). Wheat contributes the most towards public distribution system (PDS) and has become a backbone of the country's food security (Prasad and Gupta, 2012). By 2050, India will have a population of about 1.7 billion (UN report on world population prospect: The 2012 Revision) and there will be a substantial pressure on land to produce more food. Stagnation in wheat 
production, lower productivity and inferior quality of the produce is due to various constraints including inadequate and imbalanced nutrient application (Prasad, 2012).

Delayed sowing of wheat in India is very common due to the wide spread intensive cropping system which so often extended the sowing of wheat up to the January, particularly in northern plains of India where, it is generally sown after harvest of paddy, sugarcane pigeon pea etc. As a result, a portion of the maturity period of the crop is pushed forward and thus has to face higher temperatures of the summer as well as hot spells often occurring at that time. This high temperature at the time of grain in development limits the yield quality of wheat (Alkhatib and Paulson, 1984). Some of the crucial factors for choosing wheat cultivars are higher yields, greater tolerance to adverse conditions and shorter maturity (Kumar et al., 2013). The use of modern varieties of wheat and judicious fertilization are the important factors which can help the increase of wheat. The prolonged and over-use of chemicals than crop requirement resulted in human health hazards and imbalance in natural resources (Mithilesh and Abraham, 2017). Organic farming is a production system which favours maximum use of organic materials, crop residues, animal excreta, legumes, on and off farm organic wastes, growth regulators, biopesticide etc. and discourage use of synthetically produced agro-inputs for maintaining soil health, productivity and pest management under the conditions of sustainable natural resources and healthy environment. Use of organic manures have been found to be promising in arresting the decline in productivity through correction of deficiencies of secondary and micro-nutrients and its beneficial influence on the physical and biological properties of soil (Kumar and Tripathi, 2007). The judicious use of organic manures and their scientific management is important. Kshirsagar and Abraham (2012) also reported that beneficial influence of organic manures as superior and efficient source of nutrient may have enable the partitioning of dry matter into the economic parts.

\section{Materials and Methods}

Exhaustive wheat crop experiment was taken in rabi season during 2015-16 on a sandy clay loam soil having $\mathrm{pH} 7.10$, organic carbon 0.45 $\%$, medium in available NPK $(284.60,18.00$ $257.00 \mathrm{~kg} \mathrm{ha}^{-1}$ ) electrical conductivity (EC) of $0.28 \mathrm{dS} \mathrm{m}^{-1}$, at certified organic farm, SMOF. [SMOF was developed under the National Project on Organic Farming (NPOF) by the department of Agronomy, with Dr. Thomas Abraham, Professor (Agronomy) as it's Principal Investigator. The 2 hectares area has been certified by Lacon Quality Certification (P) Ltd. (Accreditation No. NPOP/NAB/006, Ministry of Commerce, Govt. of India); (Certificate No. ORG/SC/1009/001070) and the current validity was till $2018\left(9^{\text {th }}\right.$ year of certification). Naini Agricultural Institute, Sam Higginbottom University of Agricultural Technology and Sciences, Allahabad. Climate of the region is sub-tropical and semi-arid climate with the monsoon commencing from July and withdrawing by the end of September. For the intended study 15 treatments were tested under four replications by using split plot design. Three cultivars viz., PBW 373, K 9423 (Unnat Hulna) and PBW 502 were applied through five organic manure i.e., control, FYM, poultry manure vermicompost and goat manure. Recommended dose of NPK (120:80:60) were applied through FYM @ $15 \mathrm{t} \mathrm{ha}^{-1}$, poultry manure@4 t ha ${ }^{-1}$, Vermicompost $6 \mathrm{t} \mathrm{ha}^{-1}$ and goat manure $5 \mathrm{t} \mathrm{ha}^{-1}$ for $80 \mathrm{~kg} \mathrm{~N}$ and remaining $40 \mathrm{~kg}$ nitrogen applied over fish amino acid@2.5\% and panchgavya @ $3 \%$. The farm yard manure and poultry manure 
doses were mixed in the soil before sowing and fish amino acid and panchgavya were used as foliar application on the crop at 30, 44, 58 and 72 DAS. The seeds were sown by Kera method with the spacing of $22.5 \mathrm{~cm} \times 5 \mathrm{~cm}$. The seeds were primed in fresh water for 2 hours.

The crop was irrigated with four irrigations at critical stages. To provide weed free condition during critical growth period of crop and weeds was managed by incorporating them into the soil twice at 30 and 56 DAS with the help of Khurpi. Crop was harvested in the first week of April. The data on various growth, yield attributes and yield were recorded in different treatments. All the data were statistically analyzed.

\section{Results and Discussion}

\section{Effect of cultivars choice}

Cultivars data presented in (Table 1) indicated the highest number of effective tillers hill $^{-1}$ (6.17) grains spike ${ }^{-1}$, test weight, grain yield and straw yield $(50.85,42.97,3.52$ and $5.19 \mathrm{t}$ $\mathrm{ha}^{-1}$ respectively were obtained under treatment $\mathrm{V}_{3}$ PBW 502. Improvement of dry weight and yield parameter of wheat varieties might be due to heterogeneity in genetic constitution has been reported by Rawat et al., (2000). Similar cause and effect was also reported by Singh et al., (2016).

\section{Effect of source of manure}

Significant and highest number of effective tillers hill $^{-1}$ (6.79) was recorded in Poultry manure $\left(4 \mathrm{t} \mathrm{ha}^{-1}\right)$. However, FYM $\left(15 \mathrm{t} \mathrm{ha}^{-1}\right)$, vermicompost $\left(6 \mathrm{t} \mathrm{ha}^{-1}\right)$ and goat manure $(5 \mathrm{t}$ $\left.\mathrm{ha}^{-1}\right)$ found statistically at par with was Poultry manure $\left(4 \mathrm{t} \mathrm{ha}^{-1}\right)$. The organic sources may have supplied available plant nutrient directly to plants and created favorable soil environment, which increased the nutrient and water-holding capacity of soil for longer time, and ultimately better yield attribute, i.e., effective tillers (Sarma et al., 2007). Similar cause and effect was also found by Gupta et $a l$. , (2006) and Ram and Mir (2006).

Further, Poultry manure (4 $\left.\mathrm{t} \mathrm{ha}^{-1}\right)$ had significant and highest effect (Table 1) on number of grains spike ${ }^{-1}$, test weight, grain yield and straw yield $\left(52.60,43.73 \mathrm{~g} \mathrm{hill}^{-1}\right.$, $3.52 \mathrm{t} \mathrm{ha}^{-1}$ and $5.72 \mathrm{t} \mathrm{ha}^{-1}$ respectively) were recorded under treatment Poultry manure $(4 \mathrm{t}$ $\mathrm{ha}^{-1}$ ).

Organic manures increase the nutrient holding capacity of soil and minimize the effect of toxicants and also make the soil biologically active as these are good source of food and energy for soil micro-organisms and increase the activity of microbes which bring nonavailable plant nutrients into available form, thus improving the growth character (Nishant et al., 2016). This phenomenon may have worked in form of the current wheat crop. Similar results were also reported by Yawalkar et al., (1992).

\section{Interaction effect}

The appraisal of data presented in (Table 2) revealed that there was significantly interaction effect between different treatment combinations of cultivars and sources of manure. Significantly the highest number of effective tillers hill $^{-1}$ test weight grain yield (7.23, $\left.44.78 \mathrm{~g} \mathrm{hill}^{-1}, 3.95 \mathrm{t} \mathrm{ha}^{-1}\right)$ were recorded under treatment combination $\mathrm{T}_{12}$ [PBW $502+$ Poultry manure $\left.\left(4 \mathrm{t} \mathrm{ha}^{-1}\right)\right]$. However, the highest straw yield $\left(5.78 \mathrm{t} \mathrm{ha}^{-1}\right)$ recorded in treatment $\mathrm{T}_{11}$ [PBW $502+\mathrm{FYM}\left(15 \mathrm{t} \mathrm{ha}^{-1}\right)$ ]. The higher yield may be due to fact that the organic manures supply direct available nutrients such as nitrogen to the plants and these organic manures improve the proportion of water stable aggregates of the soil (Channabasanagowda et al., 2008). 
Table.1 Effect of cultivars choice and organic sources of nitrogen on plant height of wheat

\begin{tabular}{|c|c|c|c|c|c|c|}
\hline & Treatment & $\begin{array}{c}\text { Number of effective } \\
\text { tillers hill }\end{array}$ & $\begin{array}{l}\text { Number of } \\
\text { grains spike }^{-1}\end{array}$ & $\begin{array}{l}\text { Test weight } \\
\text { (g) }\end{array}$ & $\begin{array}{l}\text { Grain yield } \\
\left(\mathrm{t} \mathrm{ha}^{-1}\right)\end{array}$ & $\begin{array}{l}\text { Straw yield } \\
\quad\left(\mathbf{t ~ h a}^{-1}\right)\end{array}$ \\
\hline & CULTIVAR & & & & & \\
\hline $\mathbf{V}_{1}$ & PBW 373 & 5.92 & 50.54 & 41.65 & 3.40 & 5.06 \\
\hline $\mathrm{V}_{2}$ & K 9423 (Unnat Halna) & 5.77 & 50.10 & 41.53 & 3.27 & 4.96 \\
\hline \multirow[t]{5}{*}{$\overline{V_{3}}$} & PBW 502 & 6.17 & 50.85 & 42.97 & 3.52 & 5.19 \\
\hline & SEd $( \pm)$ & 0.19 & 0.52 & 0.51 & 0.03 & 0.05 \\
\hline & $\mathrm{CD}(\mathrm{P}=0.05)$ & - & - & - & 0.08 & 0.12 \\
\hline & $\mathrm{CV}(\%)$ & 10.52 & 3.23 & 3.85 & 3.40 & 3.00 \\
\hline & MANAGEMENT OF NITROGEN & & & & & \\
\hline $\mathbf{M}_{0}$ & Control & 4.42 & 44.13 & 38.43 & 2.04 & 3.19 \\
\hline $\mathbf{M}_{1}$ & FYM (15 t ha $\left.{ }^{-1}\right)$ & 6.35 & 52.58 & 42.86 & 3.79 & 5.58 \\
\hline $\mathbf{M}_{2}$ & Poultry manure $\left(4 \mathrm{t} \mathrm{ha}^{-1}\right)$ & 6.79 & 52.60 & 43.73 & 3.86 & 5.72 \\
\hline $\mathbf{M}_{3}$ & Vermicompost $\left(6 \mathrm{t} \mathrm{ha}^{-1}\right)$ & 6.27 & 52.28 & 42.94 & 3.75 & 5.53 \\
\hline \multirow[t]{4}{*}{$\mathbf{M}_{4}$} & Goat manure $\left(5 \mathrm{t} \mathrm{ha}^{-1}\right)$ & 5.97 & 50.88 & 42.33 & 3.53 & 5.35 \\
\hline & $\operatorname{SEd}( \pm)$ & 0.23 & 0.52 & 0.27 & 0.05 & 0.11 \\
\hline & $\mathrm{CD}(\mathrm{P}=0.05)$ & 0.46 & 1.81 & 0.56 & 0.10 & 0.23 \\
\hline & $\mathrm{CV}(\%)$ & 9.47 & 2.51 & 1.60 & 3.84 & 5.43 \\
\hline
\end{tabular}


Table.2 Interaction effect between choice of cultivars and organic sources of nitrogen on plant height of wheat

\begin{tabular}{|c|c|c|c|c|c|c|}
\hline & Treatment & $\begin{array}{l}\text { Number of effective } \\
\text { tillers } \text { hill }^{-1}\end{array}$ & $\begin{array}{l}\text { Number of } \\
\text { grains spike }{ }^{-1}\end{array}$ & $\begin{array}{c}\text { Test } \\
\text { weight }(g)\end{array}$ & $\begin{array}{l}\text { Grain yield } \\
\left(\mathrm{t} \mathrm{ha} \mathbf{h}^{-1}\right)\end{array}$ & $\begin{array}{l}\text { Straw yield } \\
\left(\mathrm{t} \mathbf{h a}^{-1}\right)\end{array}$ \\
\hline $\mathbf{T}_{0}$ & $\mathrm{~V}_{1} \mathrm{M}_{0}[\mathrm{PBW} 373+$ Control $]$ & 4.10 & 43.00 & 37.52 & 1.93 & 2.93 \\
\hline $\mathbf{T}_{1}$ & $\mathrm{~V}_{1} \mathrm{M}_{1}\left[\mathrm{PBW} 373+\mathrm{FYM}\left(15 \mathrm{t} \mathrm{ha}^{-1}\right)\right]$ & 6.16 & 53.85 & 42.33 & 3.75 & 5.50 \\
\hline $\mathbf{T}_{2}$ & $\mathrm{~V}_{1} \mathrm{M}_{2}\left[\mathrm{PBW} 373+\right.$ Poultry manure $\left.\left(4 \mathrm{t} \mathrm{ha}^{-1}\right)\right]$ & 6.86 & 53.55 & 43.39 & 3.88 & 5.80 \\
\hline $\mathbf{T}_{3}$ & $\mathrm{~V}_{1} \mathrm{M}_{3}\left[\mathrm{PBW} 373+\right.$ Vermicompost $\left.\left(6 \mathrm{t} \mathrm{ha}^{-1}\right)\right]$ & 6.29 & 52.00 & 42.74 & 3.78 & 5.58 \\
\hline $\mathbf{T}_{4}$ & $\mathrm{~V}_{1} \mathrm{M}_{4}\left[\mathrm{PBW} 373\right.$ + Goat manure $\left.\left(5 \mathrm{t} \mathrm{ha}^{-1}\right)\right]$ & 6.23 & 50.30 & 42.32 & 3.65 & 5.53 \\
\hline $\mathbf{T}_{5}$ & $\mathrm{~V}_{2} \mathrm{M}_{0}[\mathrm{~K} 9423$ (Unnat Halna) + Control $]$ & 4.96 & 45.54 & 38.27 & 1.95 & 3.08 \\
\hline $\mathrm{T}_{6}$ & $\mathrm{~V}_{2} \mathrm{M}_{1}\left[\mathrm{~K} 9423\right.$ (Unnat Halna) + FYM $\left.\left(15 \mathrm{t} \mathrm{ha}^{-1}\right)\right]$ & 5.91 & 51.30 & 42.47 & 3.70 & 5.48 \\
\hline $\mathbf{T}_{7}$ & $\mathrm{~V}_{2} \mathrm{M}_{2}\left[\mathrm{~K} 9423\right.$ (Unnat Halna) + Poultry manure $\left.\left(4 \mathrm{t} \mathrm{ha}^{-1}\right)\right]$ & 6.29 & 51.40 & 43.04 & 3.75 & 5.73 \\
\hline $\mathbf{T}_{8}$ & $\mathrm{~V}_{2} \mathrm{M}_{3}\left[\mathrm{~K} 9423\right.$ (Unnat Halna) + Vermicompost $\left.\left(6 \mathrm{t} \mathrm{ha}^{-1}\right)\right]$ & 5.96 & 51.50 & 42.14 & 3.70 & 5.53 \\
\hline $\mathbf{T}_{9}$ & $\mathrm{~V}_{2} \mathrm{M}_{4}\left[\mathrm{~K} 9423\right.$ (Unnat Halna) + Goat manure $\left.\left(5 \mathrm{t} \mathrm{ha}^{-1}\right)\right]$ & 5.77 & 50.85 & 41.77 & 3.25 & 5.00 \\
\hline $\mathbf{T}_{10}$ & $\mathrm{~V}_{3} \mathrm{M}_{0}[\mathrm{PBW} 502+$ Control $]$ & 4.20 & 43.95 & 39.50 & 2.25 & 3.58 \\
\hline $\mathbf{T}_{11}$ & $\mathrm{~V}_{3} \mathrm{M}_{1}\left[\mathrm{PBW} 502+\mathrm{FYM}\left(15 \mathrm{t} \mathrm{ha}^{-1}\right)\right]$ & 6.99 & 52.60 & 43.79 & 3.93 & 5.78 \\
\hline $\mathrm{T}_{12}$ & $\mathrm{~V}_{3} \mathrm{M}_{2}\left[\mathrm{PBW} 502+\right.$ Poultry manure $\left.\left(4 \mathrm{t} \mathrm{ha}^{-1}\right)\right]$ & 7.23 & 52.85 & 44.78 & 3.95 & 5.63 \\
\hline $\mathbf{T}_{13}$ & $\mathrm{~V}_{3} \mathrm{M}_{3}\left[\mathrm{PBW} 502+\right.$ Vermicompost $\left.\left(6 \mathrm{t} \mathrm{ha}^{-1}\right)\right]$ & 6.55 & 53.35 & 43.95 & 3.78 & 5.48 \\
\hline \multirow[t]{3}{*}{$\overline{\mathbf{T}_{14}}$} & $\mathrm{~V}_{3} \mathrm{M}_{4}\left[\mathrm{PBW} 502+\right.$ Goat manure $\left.\left(5 \mathrm{t} \mathrm{ha}^{-1}\right)\right]$ & 5.91 & 51.50 & 42.88 & 3.68 & 5.53 \\
\hline & $\operatorname{SEd}( \pm)$ & 0.39 & 0.90 & 0.48 & 0.09 & 0.19 \\
\hline & $\mathrm{CD}(\mathrm{P}=0.05)$ & 0.80 & 1.81 & - & 0.18 & 0.39 \\
\hline
\end{tabular}


Further, they also increase the adsorptive power of soil for cations and anions, particularly phosphates and nitrates and these may have been released slowly for the benefit of crop during the entire growth period, which ultimately exhibited higher yield (Singh et al., 1981).

The highest number of grains spike $^{-1}$ was recorded in treatment $\mathrm{T}_{1}$ [PBW $373+\mathrm{FYM}$ $\left(15 \mathrm{t} \mathrm{ha}^{-1}\right)$ ]. However, treatment $\mathrm{T}_{2}$ [PBW 373 + Poultry manure $\left.\left(4 \mathrm{t} \mathrm{ha}^{-1}\right)\right], \mathrm{T}_{12}$ [PBW $502+$ Poultry manure $\left(4 \mathrm{t} \mathrm{ha}^{-1}\right)$ ] and $\mathrm{T}_{13}$ [PBW 502 + vermicompost $\left.\left(6 \mathrm{t} \mathrm{ha}^{-1}\right)\right]$ were recorded in statistically at par with $\mathrm{T}_{1}$ [PBW $373+\mathrm{FYM}$ $\left.\left(15 \mathrm{t} \mathrm{ha}^{-1}\right)\right]$. The improvement in yield attributes, i.e., number of grains spike $^{-1}$ of wheat with application of organic manures may be assigned to the fact that proper decomposition and mineralization of these manures supplied available plant nutrients directly to plants and also had a solubilizing effect on fixed form of nutrients in soil (Singh and Singh, 2005). Similar phenomenon was also reported by Raghuwanshi and Umat (1994).

The highest test weight of wheat grains was observed in treatment $\mathrm{T}_{12}$ [PBW $502+$ Poultry manure $\left.\left(4 \mathrm{t} \mathrm{ha}^{-1}\right)\right]$ though nonsignificant.

\section{References}

Channabasanagowda, Biradarpatil, N.K., Patil B.N., Awaknavar, J.S., Ninganur, B.T. and Hunge Ravi. 2008. Effect of organic manures on growth, seed yield and quality of wheat. Karnataka Journal Agriculture Science 21(3) 366368.

Gupta, V., Sharma, R.S. and Vishwakarma, S.H. 2006. Long-term effect of integrated nutrient management on sustainability and soil fertility of rice (Oryza sativa) - wheat (Triticum aestivum) cropping system. Indian Journal of Agronomy 51(3): 160-164.

Kshirsagar, Satish, M., and Abraham, T. 2012. Studies on the influence of different planting systems and varieties through organic management practices on yield attributes and yield of sesame. Green Farming 3(6): 670-673.

Kumar, Alok, Tripathi, H.P. and Yadav, D.S. 2007. Correcting nutrient for sustainable crop production. Indian Journal of Fertilizers

Kumar, S.P., Alam, and N. Ali. 2013. Response of wheat (Triticum aestivum L. emend. Fori \& Poal.) Varieties to Sowing Dates. Journal of Research (BAU) 25(1): 56-59.

Mithilesh and Abraham, T. 2017. Agronomic evaluation of certified organic wheat (Triticum aestivum L.). International Journal of Current Microbiology and Applied Sciences 6(7)

Nishant, Vivek, Singh, V., Sharma, D.K., and Raju. 2016. Influence of organic and inorganic sources of nutrient uptake and yield of wheat (Triticum aestivum L.) in western Uttar Pradesh. Progressive Agriculture 16 (2): 223-228.

Raghuwanshi, R.K.S. and Umat, Rajiv 1994. Integrated nutrient management in sorghum (Sorghum bicolor)-wheat (Triticum aestivum) cropping system. Indian Journal of Agronomy 39(2): 193197

Ram, Tulasa and Mir, M.S. 2006. Effect of integrated nutrient management on yield and yield-attributing characters of wheat (Triticum aestivum). Indian Journal of Agronomy 51(3): 189-192.

Rawat, A.K., Sharma, R.S., Dubey, A.K., and Naik, K.R. 2000. Refinement of agrotechniques for improving the productivity of wheat (Triticum aestivum) under rice-wheat agro ecosystem. Indian Journal of Agronomy 45(4): 636-640. 
Sarma, A., Singh, H. and Nawal, R.K. 2007. Effect of integrated nutrient management on productivity of wheat (Triticum aestivum) under limited and adequate irrigation supplies. Indian Journal of Agronomy 52(2): 120-123.

Singh, B.P., Chahal, R.S. and Singh, Mahendra. 1981. Fertility management through organic and inorganic fertilisers in bajra-wheat crop sequence. Fertiliser News 26(8): 16-19.

Singh, C.B., Hashim, Mohammad, Kumar, Ashish, Raj, Rishi and Pandey, U.C.
2016. Performance of improved wheat (Triticum aestivum) varieties under various planting techniques in North Eastern Plain Zone of India. Journal of Community Mobilization and Sustainable Development 11(2): 145149.

Singh, Jitendra and Singh, K.P. 2005. Effect of organic manures and herbicides on yield and yield attributes of wheat. Indian Journal of Agronomy 50(4): 298291.

\section{How to cite this article:}

Sandeep Kumar and Thomas Abraham. 2018. Productivity Potential of Wheat under Certified Organic Production System. Int.J.Curr.Microbiol.App.Sci. 7(10): 281-288.

doi: https://doi.org/10.20546/ijcmas.2018.710.029 